\title{
Student's Fitness Level Survey on Marind, Asmat and Muyu Students at Kolese Pendidikan Guru High School in The Academic Year of 2017/2018
}

\author{
$1^{\text {st }}$ SSyamsudin \\ Physical Education and Recreation \\ Department, Faculty of Teacher Training \\ and Education \\ Musamus University \\ Merauke, Indonesia \\ sammymrq06@gmail.com \\ $4^{\text {th }}$ Hendra Jondry Hiskya \\ Physical Education and Recreation \\ Department, Faculty of Teacher \\ Training and Education \\ Musamus University \\ Merauke, Indonesia \\ hendramustamu@yahoo.com \\ $7^{\text {th }}$ Chyntia Novita Kalalo \\ Physical Education and Recreation \\ Department, Faculty of Teacher \\ Training and Education \\ Musamus University \\ Merauke, Indonesia \\ novita@unmus.ac.id
}

\author{
$2^{\text {nd }}$ Adi Sumarsono \\ Physical Education and Recreation \\ Department, Faculty of Teacher Training \\ and Education \\ Musamus University \\ Merauke, Indonesia \\ adi@unmus.ac.id \\ $5^{\text {th }}$ Emanuel Lewar \\ Physical Education and Recreation \\ Department, Faculty of Teacher Training \\ and Education \\ Musamus University \\ Merauke, Indonesia \\ juniorlewar@gmail.com
}

\author{
$3^{\text {rd }}$ Afif Khoirul Hidayat \\ Physical Education and Recreation \\ Department, Faculty of Teacher Training \\ and Education \\ Musamus University \\ Merauke, Indonesia \\ afif@unmus.ac.id \\ $6^{\text {th }}$ Carolus Wasa \\ Physical Education and Recreation \\ Department, Faculty of Teacher Training \\ and Education \\ Musamus University \\ Merauke, Indonesia \\ gaspar_wasa@yahoo.com
}

\begin{abstract}
Student's fitness level survey on Marind, Asmat and Muyu students at Kolese Pendidikan Guru High School in the academic year of 2017/2018. The research aims to know the fitness level of male students of Marind, Asmat, and Muyu tribes at Kolese Pendidikan Guru Khas Papua High School, Merauke Regency, in the academic year of 2017/2018. The sample of the research was taken from KPG Khas Papua. The subject of the research was the male students of Marind, Asmat and Muyu students of Kolese Pendidikan Guru Khas Papua High School of Merauke. There were 20 students from Marind, 20 students from Asmat, and 20 students from Muyu. The instrument used in the five test items, which are 60 meters sprint test, pull up test, sit up test, vertical jump test, 1200 meters sprint. The result of the research was that Marind students had an average score of the fitness level of 16.35 which was in the average category. Asmat students had an average score of the fitness level of 15.05 which was in the average category. Muyu students had an average score of the fitness level of $\mathbf{1 5 . 0 9}$ which was in the average category. In conclusion, Marind students had a better fitness level than Asmat and Muyu students. Muyu students had a better fitness level than Asmat students. Marind students dominated the power test. Asmat students dominated the arm and upper leg power test. And Muyu students dominated the speed test.
\end{abstract}

Keywords - fitness level, male students of Marind tribe, male students of Asmat tribe, male students of Muyu tribe.

\section{INTRODUCTION}

Modern life that is fully automated makes it easier for humans to carry out life activities. In everyday life, from waking up to sleeping time, we have been spoiled by technology so that everything becomes easy. Enjoying this automatic life has made us move less, without having to do meaningful physical activity. This can save the energy we have so that the energy can be used for other activities. If this is done continuously, it can eventually lead us to become immobile people. Modern living habits in most people have erased all efforts to achieve physical fitness [1].

There are a variety of ethnicities, customs and cultures in the Merauke-Papua Regency of Indonesia, including Marind, Asmat, Mappi, Muyu, and so on. In this study, the researcher was very interested in the level of physical fitness of the three tribes, namely Marind, Mappi and Muyu because these 3 tribes were the most dominant tribes in the South Papua region. This variable was also taken in relation to the place where the researcher was serving, namely at Musamus University of 
Mearuke whose students were dominated by the three tribes. Through the research, the Marind tribe has big and tall body characteristics, the Muyu tribe has short and small body, and Asmat is more likely to be moderate compared to the Marind and Asmat tribes. It is hoped that this research can be the support for sports coaches in South Papua especially to choose athletes according to the physical fitness of these three tribes.

Physical fitness is the ability to perform daily tasks diligently and with vigilance, without experiencing significant fatigue, and with enough energy to enjoy free time and face unexpected emergencies.

The Papuan son is a Papuan native. Papuans are people from the Melanesian race group consisting of indigenous tribes in the Papua Province and/or people who are accepted and recognized as indigenous Papuans by indigenous Papuan people [2]. Melanesia comes from the Dutch language, melan = black and nesos = island. Melanesia is an area that extends from the western Pacific to the Arafura Sea, north and northeast of Australia. In the western part of the island of New Guinea or more commonly called as Tanah Papua, the Melanesian Racial is so strongly echoed and often plurally becomes Papua-Melanesia in order to give an emotional affirmation or effect as stated in the Law of the Republic of Indonesia Number 21 of 2001 concerning Special Autonomy for Papua Province.

Merauke is located on Selasa Beach of Irian Jaya, near the boundary of Papua Nieuw Guinea (PNG). From Merauke, along the beach, there are many villages: Wendu, Kumbe, Onggari, Domande, Okaba, Wambi and Wamal; and many rivers: Maro, Kumbe, Bian and Bulaka, which flow to Arafura sea, in the South Beach. This region which stretches from the coast to the Digul river is an area inhabited by the Marind Tribe. There are various sub-clans from the Marind-anim tribe, namely: 1. Kaize 2. Gebze 3. Balaigeze 4. Mahuze 5. Ndiken 6. Basik-basik. In general, the Marind Tribe lives by using the natural products around them. This is what makes them one of the few tribes that still live as the gatherers, people who process their own food from nature[3].

Asmat people live on the west coast of Irian Jaya. They live in mangrove forests flanked by wide rivers in the sloping land. They inhabit the muddy land which does not have any rock and which is full of brackish water swamps around it. Their village is located along the river above the stilts facing each other. They live without knowing iron tools, and by collecting food from the forest, hunting and fishing. They build their houses all from wood and rattan, roofed with gaba-gaba or rumbia or the true sago palm and the floor is staged and made of gagar kulit ngibung [3].

The Muyu tribe is one of the large tribes originating from Merauke Papua. Muyu Region is located between the Kao and Muyu rivers above Kamka-Amupka volcano. In Mandobo area, there were large tribes namely the Awyu (Lower Digul) and Muyu (Upper Digul) tribes. Muyu people have to work hard. They must farm and raise pigs. The land for farming on the hillside is not wide and infertile. As a result, food shortages often occur. Food shortages and humid weather cause high mortality rates in this area [3].

\section{RESEARCH METHOD}

This research was conducted in the field of Kolese Pendidikan Guru (KPG Khas Papua High School of Merauke Regency on Wednesday, 7 February 2018. The population in this study were the male students of class X Kolese Pendidikan Guru (KPG) Khas Papua High School of Merauke Regency, totaling 60 male students, which consist of $20 \mathrm{X}-1$ students (Marind), 20 X-2 students (Asmat) and 20 X-3 students (Muyu). The samples were taken by using the Total Sampling technique in which all populations were the whole part of the research sample.

The instrument used in this research was Indonesian Fitness Level Test of 2010 of the male category with the age of 16-19 years old which consists of five test items namely 60 meters sprint test, pull-up test, sit-up test, vertical jump test, 1200 meters sprint[4], with the following assessment rubric:

1. First:60 meters (age of 16-19 years old).

This test aims to measure speed. Straight trajectories are the main means of conducting this test. The start and finish lines are clarified so that the research subjects clearly see the finish line. The researcher is assisted by colleagues to record the time and also to make the track.

2. Second: pull up.

This test aims to measure the strength and endurance of the arm and shoulder muscles. Stakes with a height of 2.2 meters are made as the main means in this test. The hand placement must also be in accordance with the test requirement as shown in Figure 1.

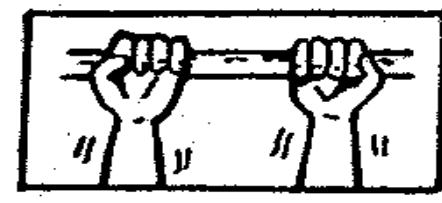

Figure 1. The hand position of pull up test

The calculated movement is to lift the body by bending both arms so that the chin touches or is above the single crossbar. Then, the position returns to the initial stance. This movement is counted once. During the movement, the position of the head to the toe is a straight line. This movement is done repeatedly without resting as many as possible for 60 seconds.
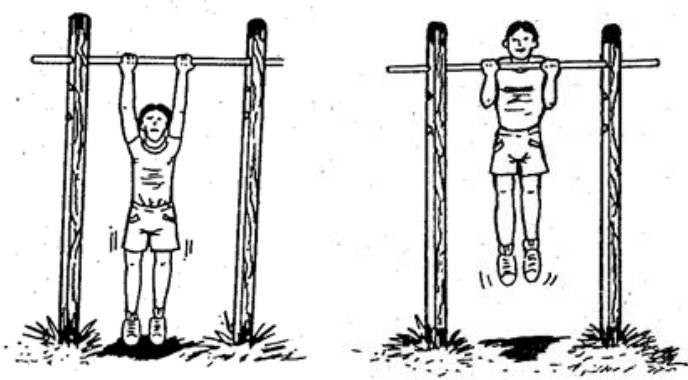

Figure 2. The position of the body of pull up test

3. Third: sit up. 
This test aims to measure abdominal muscle strength. Flat, clean floors are a means for this test, in addition to a stopwatch to record time.

The counts are considered valid when the elbow touches the thigh from the supine sleeping position as shown in Figure 3.
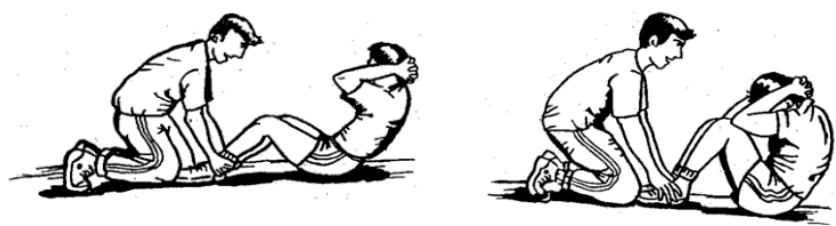

Figure 3. The movement of the sit-up test

4. Fourth: vertical jump.

This test aims to measure the explosive power of leg muscles. Scaleboards must be measured at zero points on the floor. The score is taken from the highest jump results from 3 times of experiment which is reduced by the height of achievement without jumping. The movement of the vertical jump is shown in the following figure.

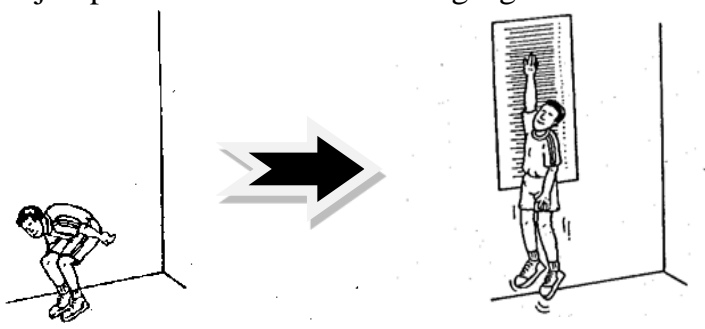

Figure 4. The movement of vertical jump test

5. Fifth: 1200 meters sprint (age of 16-19 years old).

This test aims to measure the cardiac, blood circulation and breathing endurance. The $1.2 \mathrm{~km}$ track is prepared in the implementation.

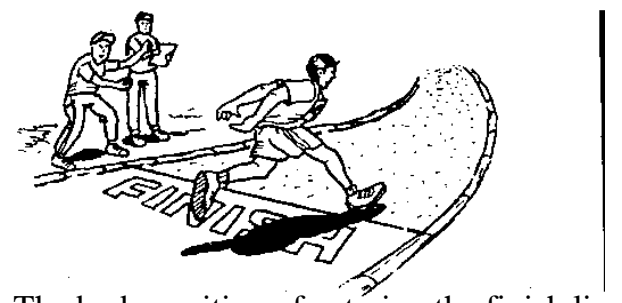

Figure 5. The body position of entering the finish line

The score of the test results is then converted according to the TKJI (Indonesian Fitness Level Test) norm according to the age group. In this study, the age group used was 16-19 years[5]. The norm for filling in the score is according to the following table:
Table I. The Table of TKJI Scores (For 16-19 years old male)

\begin{tabular}{|c|c|c|c|c|c|c|}
\hline Score & $\begin{array}{l}\mathbf{6 0} \\
\text { meters } \\
\text { sprint }\end{array}$ & Pull up & Sit up & $\begin{array}{l}\text { Vertical } \\
\text { jump }\end{array}$ & $\begin{array}{l}1200 \\
\text { meters } \\
\text { sprint }\end{array}$ & Score \\
\hline 5 & $\begin{array}{l}\text { Up to - } \\
7,2 \text { " }\end{array}$ & $\begin{array}{l}19- \\
\text { above }\end{array}$ & $\begin{array}{l}41 \\
\text { above }\end{array}$ & $\begin{array}{l}73 \\
\text { above }\end{array}$ & $\begin{array}{l}\text { Up to - } \\
\text { 3'14" }\end{array}$ & 5 \\
\hline 4 & $\begin{array}{l}7.3^{\prime \prime} \quad- \\
8,3^{\prime \prime}\end{array}$ & $14-18$ & $30-40$ & $60-72$ & $\begin{array}{l}3 ' 15 " \\
\text { 4'25" }\end{array}$ & 4 \\
\hline 3 & $\begin{array}{ll}8,4 " & - \\
9,6 " & \end{array}$ & $9-13$ & $21-29$ & $50-59$ & $\begin{array}{l}\text { 4'26" } \\
\text { 5'12" }\end{array}$ & 3 \\
\hline 2 & $\begin{array}{l}9,7 ” \quad- \\
11,0 "\end{array}$ & $5-8$ & $10-20$ & $39-49$ & $\begin{array}{l}5,13 " \\
6,33 " \quad-\end{array}$ & 2 \\
\hline 1 & 11,1 " etc. & $0-4$ & $0-9$ & 38 etc & $64^{\prime} 3$ ' etc & 1 \\
\hline
\end{tabular}

Source: Ministry of Education, 2010

To get the final result, it needs to be replaced in the same unit that is SCORE. After the rough results of each test are changed to a unit of score, then it proceeds by adding up the scores of the five TKJI points. The summation results are used for the basic determination of adolescent physical fitness classification[6].

Table II. The Norm of Indonesian Fitness Level Test (for male and female)

\begin{tabular}{|l|l|lc|}
\hline No & Total of Score & Fitness Classification \\
\hline 1. & $22-25$ & Excellent & ( E ) \\
\hline 2. & $18-21$ & Good & ( G ) \\
\hline 3. & $14-17$ & Fair & ( F ) \\
\hline 4. & $10-13$ & Poor & ( P ) \\
\hline 5. & $5-9$ & \multicolumn{3}{|c|}{ Very Poor } & ( VP ) \\
\hline \multicolumn{4}{|c|}{ Source: Ministry of Education, 2010 } \\
\hline
\end{tabular}

\section{RESUlT AND DISCUSSION}

The finding of the research is in the form of data that were divided into three groups based on the variables of the research[7]. The point researched was the fitness level of Marind male students (X1), Asmat male students (X2), and Muyu male students (X3).

The description of the data obtained is explained below.

1. The Data of Marind Students' Fitness Level Test Result 
Table III. Marind Students' Fitness Level Test Result

\begin{tabular}{|c|c|c|c|c|c|c|c|c|}
\hline \multirow{2}{*}{ NO } & \multirow{2}{*}{ NAME } & \multicolumn{6}{|c|}{ SCORE PER TEST ITEM } & \multirow{2}{*}{ CLASSIFICATION } \\
\hline & & 1 & 2 & 3 & 4 & 5 & $\begin{array}{l}\text { TOTAL } \\
\text { SCORE }\end{array}$ & \\
\hline 1 & S1 & 3 & 4 & 3 & 3 & 2 & 15 & FAIR \\
\hline 2 & S2 & 4 & 5 & 4 & 3 & 3 & 19 & GOOD \\
\hline 3 & S3 & 4 & 4 & 4 & 3 & 2 & 17 & FAIR \\
\hline 4 & S4 & 3 & 3 & 3 & 2 & 2 & 13 & POOR \\
\hline 5 & S5 & 3 & 4 & 4 & 2 & 2 & 15 & FAIR \\
\hline 6 & S6 & 3 & 4 & 3 & 3 & 2 & 15 & FAIR \\
\hline 7 & S7 & 4 & 5 & 4 & 3 & 3 & 19 & GOOD \\
\hline 8 & S8 & 4 & 4 & 4 & 2 & 2 & 16 & FAIR \\
\hline 9 & S9 & 4 & 5 & 4 & 2 & 3 & 18 & GOOD \\
\hline 10 & S10 & 4 & 3 & 4 & 3 & 2 & 16 & FAIR \\
\hline 11 & S11 & 4 & 5 & 4 & 3 & 2 & 18 & GOOD \\
\hline 12 & $\mathrm{~S} 12$ & 3 & 3 & 3 & 2 & 2 & 13 & POOR \\
\hline 13 & S13 & 3 & 4 & 4 & 2 & 2 & 15 & FAIR \\
\hline 14 & S14 & 3 & 4 & 3 & 3 & 2 & 15 & FAIR \\
\hline 15 & S15 & 4 & 5 & 4 & 3 & 3 & 19 & GOOD \\
\hline 16 & S16 & 4 & 4 & 4 & 2 & 2 & 16 & SEDANG \\
\hline 17 & S17 & 4 & 5 & 4 & 2 & 3 & 18 & BAIK \\
\hline 18 & S18 & 4 & 3 & 4 & 3 & 2 & 16 & FAIR \\
\hline 19 & S19 & 4 & 5 & 4 & 3 & 2 & 18 & GOOD \\
\hline 20 & S20 & 4 & 4 & 4 & 2 & 2 & 16 & FAIR \\
\hline & & Aver: & & & & & 16.35 & FAIR \\
\hline
\end{tabular}

Based on the results of the calculation of the data, the Marind students have the best level of physical fitness. The researchers assume that the natural condition of the swamps that become their residence makes them need to have the strong physical condition to survive in the area. Another factor is that most of the Marind tribes studied have additional activities after going home from school. They earn a living by helping parents find natural resources, either hunting, gardening, or fishing. It can be seen from the data shown that in tests 2 and 3 which are the tests that measure strength, Marind students dominate so that it is very good if the coach or teacher and parents develop their potential in sports that promote strength such as javelin and shot put.
2. The Data of Asmat Students' Fitness Level Test Result

Table IV. Asmat Students' Fitness Level Test Result

\begin{tabular}{|c|c|c|c|c|c|c|c|c|}
\hline \multirow{2}{*}{ NO } & \multirow{2}{*}{ NAME } & \multicolumn{6}{|c|}{ SCORE PER TEST ITEM } & \multirow{2}{*}{ CLASSIFICATION } \\
\hline & & 1 & 2 & 3 & 4 & 5 & $\begin{array}{l}\text { TOTAL } \\
\text { SCORE }\end{array}$ & \\
\hline 1 & S1 & 3 & 5 & 3 & 3 & 2 & 16 & FAIR \\
\hline 2 & $\mathrm{~S} 2$ & 3 & 4 & 2 & 2 & 2 & 13 & POOR \\
\hline 3 & S3 & 1 & 2 & 4 & 2 & 1 & 10 & POOR \\
\hline 4 & S4 & 4 & 5 & 3 & 2 & 2 & 16 & FAIR \\
\hline 5 & S5 & 4 & 3 & 3 & 3 & 2 & 15 & FAIR \\
\hline 6 & S6 & 4 & 4 & 4 & 4 & 1 & 17 & FAIR \\
\hline 7 & S7 & 5 & 4 & 4 & 3 & 2 & 18 & GOOD \\
\hline 8 & S8 & 4 & 3 & 4 & 3 & 2 & 16 & FAIR \\
\hline 9 & S9 & 3 & 3 & 3 & 3 & 2 & 14 & FAIR \\
\hline 10 & $\mathrm{~S} 10$ & 4 & 5 & 4 & 3 & 2 & 18 & BAIK \\
\hline 11 & S11 & 3 & 3 & 3 & 2 & 2 & 13 & POOR \\
\hline 12 & $\mathrm{~S} 12$ & 3 & 3 & 3 & 2 & 2 & 13 & POOR \\
\hline 13 & $\mathrm{~S} 13$ & 5 & 4 & 4 & 3 & 2 & 18 & GOOD \\
\hline 14 & S14 & 4 & 3 & 4 & 3 & 2 & 16 & FAIR \\
\hline 15 & S15 & 3 & 3 & 3 & 3 & 2 & 14 & FAIR \\
\hline 16 & S16 & 4 & 5 & 4 & 3 & 2 & 18 & GOOD \\
\hline 17 & S17 & 3 & 3 & 3 & 2 & 2 & 13 & POOR \\
\hline 18 & $\mathrm{~S} 18$ & 3 & 3 & 3 & 2 & 2 & 13 & POOR \\
\hline 19 & S19 & 4 & 3 & 4 & 3 & 2 & 16 & FAIR \\
\hline 20 & $\mathrm{~S} 20$ & 3 & 3 & 3 & 3 & 2 & 14 & FAIR \\
\hline & & Aver & & & & & 15.05 & FAIR \\
\hline
\end{tabular}

Based on the data above, the average score of the Asmat students is 15.05 with the fair category. Thus, the Asmat tribe has the lowest physical fitness level. Researchers assume that their life at their original place has a severe natural challenge but the facilities and access to transportation used are in the form of boats so that the speed and explosive power and body resistance are less compared to the Marind and Muyu tribes. However, the Asmat tribe students have a high score on the arm muscle strength test so that rowing and other sports that require arm muscle strength are recommended for Asmat. 
3. The Data of Muyu Students' Fitness Level Test Result

Table V. Asmat Students' Fitness Level Test Result

\begin{tabular}{|c|c|c|c|c|c|c|c|c|}
\hline \multirow{2}{*}{ NO } & \multirow{2}{*}{ NAME } & \multicolumn{6}{|c|}{ SCORE PER TEST ITEM } & \multirow{2}{*}{ CLASSIFICATION } \\
\hline & & 1 & 2 & 3 & 4 & 5 & $\begin{array}{l}\text { TOTAL } \\
\text { SCORE }\end{array}$ & \\
\hline 1 & S1 & 4 & 3 & 4 & 3 & 1 & 15 & FAIR \\
\hline 2 & $\mathrm{~S} 2$ & 4 & 5 & 2 & 3 & 1 & 15 & FAIR \\
\hline 3 & S3 & 4 & 4 & 4 & 2 & 2 & 16 & FAIR \\
\hline 4 & S4 & 4 & 5 & 3 & 3 & 2 & 17 & FAIR \\
\hline 5 & S5 & 4 & 4 & 5 & 3 & 3 & 19 & GOOD \\
\hline 6 & S6 & 4 & 5 & 4 & 3 & 1 & 17 & FAIR \\
\hline 7 & S7 & 4 & 3 & 3 & 3 & 3 & 16 & FAIR \\
\hline 8 & S8 & 3 & 3 & 3 & 3 & 2 & 14 & FAIR \\
\hline 9 & S9 & 4 & 4 & 3 & 3 & 2 & 16 & FAIR \\
\hline 10 & S10 & 4 & 3 & 4 & 3 & 2 & 16 & FAIR \\
\hline 11 & S11 & 3 & 3 & 3 & 2 & 2 & 13 & POOR \\
\hline 12 & $\mathrm{~S} 12$ & 4 & 3 & 2 & 3 & 2 & 14 & FAIR \\
\hline 13 & $\mathrm{~S} 13$ & 4 & 4 & 3 & 3 & 2 & 16 & FAIR \\
\hline 14 & S14 & 4 & 4 & 5 & 3 & 3 & 19 & GOOD \\
\hline 15 & S15 & 4 & 5 & 4 & 3 & 1 & 17 & FAIR \\
\hline 16 & S16 & 4 & 3 & 4 & 3 & 2 & 16 & FAIR \\
\hline 17 & S17 & 4 & 2 & 3 & 2 & 2 & 13 & POOR \\
\hline 18 & S18 & 4 & 3 & 2 & 3 & 2 & 14 & FAIR \\
\hline 19 & S19 & 4 & 4 & 3 & 3 & 2 & 16 & FAIR \\
\hline 20 & S20 & 4 & 4 & 4 & 4 & 3 & 19 & GOOD \\
\hline & & Avera & & & & & 15.90 & FAIR \\
\hline
\end{tabular}

The results show that the score for the Muyu students is 15.90 and in the fair category. Researchers analyzed the state of their nature that consists of some rocks and the condition that the children still often help their parents find natural products from hunting and farming strongly support the physical fitness level of the Muyu tribe students. The results show that the existence of a very dominant score in the first test which is a 60-meter sprint. With this result, sports that require speed are recommended for Muyu tribe students such as sprint.

\section{CONCLUSION}

Based on the discussion above, it can be seen that the Marind students who have the best physical fitness level with an average score of 16.35 followed by the Muyu students who have an average score of 15.90 and the Asmat students who have the lowest average score of 15.05. Thus, the result was that the Marind students have a better physical fitness level than the Muyu and Asmat tribe students, while the Muyu students have better physical fitness than the Asmat tribe. However, each tribe has advantages in each test item. Marind students are good at their strength test. Asmat students are good at the upper leg strength test while the Muyu students are good at speed test item. Therefore, it is expected that the results of this study can be the input for teachers, coaches, and parents in determining sports for Papuan children, especially for Marin, Asmat, and Muyu students.

\section{ACKNOWLEDGMENT}

We thank Universitas Musamus for facilities, supports, and publications.

\section{REFERENCES}

[1] Suwartono, Dasar-dasar Metodologi Penelitian. Yogyakarta: Andi Offset, 2014

[2] Mansoben, "International Conference On Papua Cultural Diversity in the Mosaik of Indonesia Culture," 2011, p. 12.

[3] J. Duivenvoorde, Gereja Katolik di Irian Selatan. Merauke, 1999.

[4] DEPDIKNAS, Buku Kesehatan Anak Didik. Jakarta, 2010.

[5] Supardi, Aplikasi Statistika dalam Penelitian. Jakarta: Prima Ufuk Semesta, 2011.

[6] Sukardi, Metodologi Penelitian Pendidikan. Jakarta: Bumi Aksara, 2011.

[7] Partrino, Statistika Inferensial. Yogyakarta, 2009. 